\title{
Effectiveness of Mexican oregano essential oil from the Dominican Republic (Lippia graveolens) against maize pests (Sitophilus zeamais and Fusarium verticillioides)
}

Peschiutta, M.L.; J.S. Arena, A. Ramirez Sanchez, E. Gomez Torres, R.P. Pizzolitto, C. Merlo, M.P. Zunino, A.B. Omarini, J. S.Dambolena and J. A. Zygadlo

\begin{abstract}
SUMMARY
The insecticidal and antifungal properties of Mexican oregano (Lippia graveolens) essential oil from the Dominican Republic were investigated under laboratory conditions against two main pests of stored grains: Sitophilus zeamais and Fusarium verticillioides. Although oregano essential oil at 600 $\mu \mathrm{l} / \mathrm{l}$ air did not result in a significant mortality of $S$. zeamais after 24 hours of exposure by fumigation, this essential oil was a powerful acetylcholinesterase (AChE) inhibitor in vitro. One of the main components of oregano essential oil, p-cymene, presented fumigant toxicity and AChE inhibition activity against the maize weevil. The $L$. graveolens essential oil antifungal activity against F. verticillioides was evaluated at 50,100 and $200 \mu \mathrm{l} / \mathrm{l}$, and it was found that growth parameters were affected by the presence of oregano essential oil in the media, whereas FB, production was not inhibited. The results demonstrate that oregano essential oil and p-cymene can be used as alternatives to synthetic pesticides against $F$. verticillioides and $S$. zeamais, respectively.
\end{abstract}

Key words: Acetylcholinesterase inhibition, fungal pathogen, Lippia graveolens, maize pest control, maize weevil.

Peschiutta, M.L.; J.S. Arena, A. Ramirez Sanchez, E. Gomez Torres, R.P. Pizzolitto, C. Merlo, M.P. Zunino, A.B. Omarini, J. S.Dambolena y J. A. Zygadlo, 2016. Efectividad del aceite esencial de orégano mexicano de República Dominicana (Lippia graveolens) contra plagas del maíz (Sitophilus zeamais y Fusarium verticillioides). Agriscientia 33 (2): 89-97

\section{RESUMEN}

Se estudiaron en condiciones de laboratorio las propiedades insecticidas y fungicidas del aceite esencial de orégano mexicano (Lippia graveolens) de 
República Dominicana contra dos plagas principales de granos almacenados: Sitophilus zeamais y Fusarium verticillioides. Aunque el aceite esencial de orégano a $600 \mu \mathrm{l} / \mathrm{l}$ de aire no resultó en una mortalidad significativa de $S$. zeamais después de 24 horas de exposición a la fumigación, fue un potente inhibidor de la acetilcolinesterasa (AChE) in vitro. El p-cimeno, uno de los principales componentes del aceite esencial, presentó actividad fumigante y de inhibición de la AChE contra el gorgojo del maíz. Además se evaluó la actividad antifúngica frente a F. verticillioides a 50, 100 y $200 \mu \mathrm{l} / \mathrm{l}$ y se encontró que los parámetros de crecimiento del hongo fueron afectados por la presencia del aceite esencial de orégano en el medio, mientras que la producción de fumonisina $B_{1}\left(F B_{1}\right)$ no se inhibió. Los resultados demuestran que el aceite esencial de orégano y el p-cimeno se pueden usar como alternativas a los pesticidas sintéticos contra F. verticillioides y S. zeamais, respectivamente.

Palabras clave: Inhibición de la acetilcolinesterasa, hongo patógeno, Lippia graveolens, control de plagas del maíz, gorgojo del maíz.

M.L. Peschiutta, J.S. Arena, R.P. Pizzolitto, C. Merlo, M.P. Zunino, J.S. Dambolena, y J. A. Zygadlo: Instituto Multidisciplinario de Biología Vegetal, IMBIV-CONICET, Avenida Vélez Sarsfield 1611, X5016GCA, Córdoba, Argentina. A. Ramirez Sanchez, E. Gomez Torres: Coordinación de Biotecnología Aplicada al Medio Ambiente, IIBI, Santo Domingo, República Dominicana. A.B. Omarini: Centro de Investigaciones y Transferencia de Entre Ríos, CITER-CONICET-UNER, Av. Monseñor Tavella 1450, CP 3200, Concordia, Entre Ríos, Argentina. Correpondencia a: jzygadlo@unc.edu.ar

\section{INTRODUCTION}

The maize weevil Sitophilus zeamais Motschulsky (Coleoptera: Curculionidae) is a serious pest of stored grains, especially corn. It consumes the grains and creates the conditions that favor the development of fungi, resulting in major losses, both quantitative and qualitative (Caneppele et al., 2003; Trematerra et al., 2013). Fusarium verticillioides (Sacc,) Nirenberg (= F. moniliforme Sheldon teleomorph Giberella fujikuroi [Sawada] Ito in Ito \& Kimura) is a frequent fungal pathogen in stored maize. In addition, $F$. verticillioides is one of the most important mycotoxin fumonisin $\mathrm{B}_{1}\left(\mathrm{FB}_{1}\right)$ producers. It can be produced during maize storage and represents a major problem due to its toxicological implications for humans and farm animals (Stockmann-Juvala \& Savolainen, 2008; Theumer et al., 2010). The use of synthetic fumigants, such as methyl bromide, phosphine and sulfuryl fluoride, is the most widespread method to control stored product pests. However, the use of these compounds has led to a variety of problems including the development of insecticide resistance (Pimentel et al., 2009), toxic residual effects in food grains, toxicity to non-target organisms and environmental pollution (Isman, 2006). Moreover, the increasing public awareness of pesticide safety and possible damage to the environment has resulted in greater attention being given to the control of stored food pests by means of natural products (Rajendran \& Sriranjini, 2008), of which essential oils (EOs) are considered to be an interesting alternative because of their effectiveness and versatility. In fact, their volatility and chemical diversity makes them excellent fumigants, insecticides, fungicides and repellents. The use of EOs as low-risk biopesticides has increased considerably owing to their popularity with organic farmers and environmentally conscious consumers (Rajendran \& Sriranjini, 2008; Gleiser \& Zygadlo, 2009; Regnault-Roger et al., 2012; Hernández-Lambraño et al., 2014; Sousa et al., 2015), with this demand for naturally active compounds such as EOs having stimulated the search for these chemicals in biodiversity hotspots.

Lippia graveolens Kunth (Lamiales: Verbenaceae), one of the most commercial species within the genus Lippia, is an aromatic plant commonly known as Mexican oregano or oreganillo. Interest in this species is increasing due to its insecticidal and antimicrobial activities (Cavalcanti et al., 2004; Gleiser \& Zygadlo, 2007; Bueno-Durán et al., 2013) as a result of its chemical constituents, such as thy- 
mol and carvacrol. In this context, the aim of this study was to analyze the EO composition of $L$. graveolens growing in the Dominican Republic, and to evaluate the insecticidal activity and acetylcholinesterase (AChE) inhibition of L. graveolens EO and its main components against $S$. zeamais. The antifungal properties and $\mathrm{FB}_{1}$ inhibition of Mexican oregano EO from the Dominican Republic against the $F$. verticillioides strain M3125 were measured.

\section{MATERIALS AND METHODS}

\section{Insects}

Adults of $S$. zeamais were obtained from Metan, Salta, Argentina, and were maintained in sealed containers (10 I) under controlled conditions $\left(26^{\circ} \mathrm{C}\right.$ and $60 \%$ relative humidity) with a lighting regime of $12: 12$ hours $(D: L)$. The insects were reared on whole maize grains, and all bioassays were carried out under the same environmental conditions and in complete darkness (FAO, 1974). The colony was kept in the laboratory for two years without being exposed to insecticides before testing. The unsexed adult weevils used in all the experiments were approximately two weeks old.

\section{Fungal strain}

Fusarium verticillioides (Sacc) Niremberg (= F. moniliforme Sheldon teleomorph Giberella fujikuroi [Sawada] Ito in Ito \& Kimura (Leslie et al., 2006) strain M3125 (provided by Dr. Robert Proctor, United States Department of Agriculture, Agricultural Research Service, National Center for Agricultural Utilization Research, Peoria, IL, United States) isolated from maize in California (fumonisin-producing strain) was used in all the antifungal tests (Leslie et al., 1992).

\section{Essential oil and pure compounds}

Lippia graveolens Kunth samples were collected in commercial crops in Santo Domingo, Dominican Republic. The aerial parts of the plants were air dried, chopped into small pieces using a mill with rotary knives, and extracted by hydro-distillation for 2 hours in a Clevenger's apparatus in order to collect their vaporized EO. The EO obtained was stored in dark glass tubes under refrigeration $\left(4^{\circ} \mathrm{C}\right)$ until evaluation.

The density of EO was measured by gravimetric method and found to be $0.93 \mathrm{~g} / \mathrm{ml}$ at room temperature $\left( \pm 2^{\circ} \mathrm{C}\right)$. Identification of the constituents in EO was determined using electron impact mass spectra (El-MS) obtained from gas chromatography-mass spectrometry (GC-MS) and by co-injection of standards (Sigma Aldrich Co. Buenos Aires, Argentina), with the mass spectra libraries Adams, NIST and a homemade library being utilized. Compound concentrations were expressed as a percentage of the peaks area, and the retention index (RI) of each compound was obtained for a homologous series of n-alkanes $\mathrm{C}_{9}-\mathrm{C}_{20}$ (Sigma Aldrich Co. Buenos Aires, Argentina). GC-MS was performed on a GC-MS Perkin Elmer 600 with the chromatography conditions being as follows: DB-5 capillary column, which was programmed: temperature profile of $60^{\circ} \mathrm{C}$ for 5 minutes, ramped up to $170{ }^{\circ} \mathrm{C}$ at $4{ }^{\circ} \mathrm{C} /$ minute, and then to $240{ }^{\circ} \mathrm{C}$ at $20^{\circ} \mathrm{C}$ /minute; injector temperature $250^{\circ} \mathrm{C}$; detector temperature $250{ }^{\circ} \mathrm{C}$; carrier gas, $\mathrm{H}_{2}$ at $45 \mathrm{~cm} / \mathrm{second}$, split into $50 \mathrm{ml} /$ minute. The identification and quantification of limonene, $\beta$-phellandrene and 1,8-cineole were carried out using Carbowax capillary columns, at the same conditions mentioned above for the DB-5 column.

\section{Fumigation toxicity assay}

Insecticidal activity against $S$. zeamais was evaluated using a fumigant toxicity assay previously described by Herrera et al. (2015a), with modifications. Different amounts of oregano EO and its main pure compounds ( $p$-cymene, thymol and carvacrol) were applied to Whatman filter paper disks (2 $\mathrm{cm}$ diameter) placed on the underside of the screw cap of fumigation chambers (30 ml-glass vials) at doses from 75 to $600 \mu \mathrm{l} / \mathrm{l}$ air. A piece of voile was also placed under the screw cap to avoid direct contact of the weevils with the EOs. Ten adults of $S$. zeamais and $5 \mathrm{~g}$ of whole maize grains were placed in each vial, with the inclusion of corn allowing the natural conditions in a silo to be mimicked. Five replicates per dose were carried out, and control treatments were performed under the same conditions without EOs or pure compounds (negative control) and with 2,2-dichlorovinyl dimethyl phosphate (DDVP) compound $0.06 \mu \mathrm{l} / \mathrm{l}$ air (positive control). This latter compound was used as a positive control due to its high vapor pressure and its known insecticidal activity. Insect mortality was evaluated after 24 hours, and the mortality percentages and $\mathrm{LC}_{50}$ and $\mathrm{LC}_{95}$ values were then calculated.

\section{In vitro AChE inhibition tests}

The effects of oregano EO and its main components ( $p$-cymene, thymol and carvacrol) on ace- 
tylcholinesterase (AChE) activities were examined at different concentrations $(0.09,0.19,0.46,1.39$, $4.65,13.95$ and $23.25 \mathrm{mg} / \mathrm{ml}$ for oregano $\mathrm{EO}$, and $0.025,0.05,0.1$ and $0.5 \mathrm{mM}$ for its components). Untreated whole $S$. zeamais adults $(0.1 \mathrm{~g})$ were homogenized with $1 \mathrm{ml}$ phosphate buffer ( $\mathrm{pH} 7.4)$, and then the homogenate was centrifuged (6500 rpm for 20 minutes at $0^{\circ} \mathrm{C}$ ) and the supernatant was used as crude AChE. Inhibition of AChE was then determined by the colorimetric method of Ellman et al. (1961) using acetylthiocholine iodide (ATChl) at $2.5 \mathrm{mM}$ (Sigma Aldrich Co., St. Louis, MO USA) as the substrate. Enzyme aliquots $(20 \mu \mathrm{l})$ and 5,5-dithio-bis (2-nitrobenzoic) acid (DTNB) (20 $\mu \mathrm{l}$ of $4 \mathrm{mM}$ ) were added to $0.1 \mathrm{M}$ phosphate buffer $(\mathrm{pH} 7.4 ; 120 \mu \mathrm{l})$, and the EO active compounds $(20 \mu \mathrm{l})$ prepared in absolute ethanol were added to this mixture. Control treatments used the addition of absolute ethanol $(20 \mu \mathrm{l})$ instead of an active compound. All mixtures were incubated at $35^{\circ} \mathrm{C}$ for 15 minutes, and the reactions were started by adding ATChl $(20 \mu \mathrm{l})$, with absorbance being measured at $412 \mathrm{~nm}$ using a spectrophotometer (Model $680 \mathrm{Mi}-$ croplate Reader, Bio-Rad).

AChE activity was examined, with each treatment being corrected by blanks for nonenzymic hydrolysis. The inhibition percentage of AChE activity was calculated as follows: AChE inhibition \% = (ODC-ODT)/ODC $\times 100$, where ODC is the optical density of control and ODT is the optical density of the treatment. Each concentration was analyzed for triplicate assays, and the mid-point inhibitive concentration $\left(\mathrm{IC}_{50}\right)$ values were determined graphically from the inhibition curves (log inhibitor concentration vs percentage of inhibition) (MohammadiFarani et al., 2013).

\section{In vivo AChE inhibition tests}

For in vivo AChE inhibition tests, S. zeamais adults were cultured for 24 hours in the absence or presence of Mexican oregano EO (150 $\mu \mathrm{l} / \mathrm{l}$ air), with the experimental conditions and procedures carried out as described above. Homogenates were prepared in phosphate buffer $(0.1 \mathrm{M}, \mathrm{pH} 7.4)$ and kept on ice during the homogenization, with approximately fifty insects $(0.1 \mathrm{~g})$ per $\mathrm{ml}$ of buffer being used for each sample and the activity of AChE being determined immediately after the preparation of the homogenates.

\section{Effect of Lippia graveolens EO on fungal growth and fumonisin production}

Fusarium verticillioides M3125 inoculum was grown on Czapek-dox agar Petri plates for 7 days at $28{ }^{\circ} \mathrm{C}$ in the dark to allow profuse sporulation. Then, sterile distilled water was added to each plate, and a conidia suspension was obtained by scraping the colony surface with a sterile Drigalsky spatula and filtering it through a cheesecloth. The suspension was then counted using a Neubauer chamber and adjusted to $10^{6} \mathrm{conidia} / \mathrm{ml}$.

The antifungal activity was tested at different concentrations of $L$. graveolens EO using CzapekDox agar in Petri dishes $(90 \mathrm{~mm})$. The culture medium was autoclaved at $120^{\circ} \mathrm{C}$ for 15 minutes, and before cooling at $45^{\circ} \mathrm{C}$, an appropriate volume of EO was added to the media to obtain concentrations of 50; 100 and $200 \mu \mathrm{l} / \mathrm{l}$. Czapek-Dox agar plates were inoculated centrally with $10 \mu \mathrm{l}$ of the conidia suspension and incubated in the dark at 28 ${ }^{\circ} \mathrm{C}$. Czapek-Dox Agar plates without the addition of EO were used as control.

The amount of radial mycelial growth was determined by periodical measurement of two rightangled diameters of the colonies, until the colonies reached the edge of the plate. Colony diameters versus time were plotted, and radial growth rates $(\mathrm{mm} /$ day) were evaluated from the slope by linear regression. Lag phase was determined as the abscissa from these growth rate curves.

To evaluate $\mathrm{FB}_{1}$ biosynthesis, the inoculated plates were incubated in the dark at $28{ }^{\circ} \mathrm{C}$ for 28 days. After this incubation, the agar in the experimental plates was dried for 96 hours at $60{ }^{\circ} \mathrm{C}$ in a forced-air oven before being ground to a fine dry powder. Finally, $10 \mathrm{ml}$ of water was added to the dried agar, and $\mathrm{FB}_{1}$ was extracted by shaking the dried dishes with water for 120 minutes on an orbital shaker, after which the mixture was centrifuged at $5000 \mathrm{rpm}$ for 15 minutes. All experiments were performed in triplicate.

\section{Fumonisin $B_{1}$ quantification}

$\mathrm{FB}_{1}$ quantification was carried out according to a methodology described by Shephard et al.(2000). Briefly, samples $(1000 \mu \mathrm{l})$ from the $\mathrm{FB}_{1}$ extracts were diluted with acetonitrile (1:1), and then an aliquot $(50 \mu \mathrm{l})$ was derivatized with $200 \mu \mathrm{l}$ of a solution prepared by adding $5 \mathrm{ml}$ of $0.1 \mathrm{M}$ sodium tetraborate and $50 \mu \mathrm{l}$ of 2-mercaptoethanol to $1 \mathrm{ml}$ of methanol containing $40 \mathrm{mg}$ of o-phthaldialdehyde. The analysis of the derivatized samples was performed using a Perkin Elmer HPLC equipped with a fluorescence detector with the wavelengths used for excitation and emission being found to be 335 $\mathrm{nm}$ and $440 \mathrm{~nm}$, respectively, and with an analytical reverse phase column $C_{18}(150 \mathrm{~mm} \times 4.6 \mathrm{~mm}$ in- 
ternal diameter and $5 \mu \mathrm{m}$ particle size) connected to a precolumn $\mathrm{C}_{18}(20 \mathrm{~mm} \times 4.6 \mathrm{~mm}$ and $5 \mu \mathrm{m}$ particle size). Methanol and $\mathrm{NaH}_{2} \mathrm{PO}_{4} 0.1 \mathrm{M}(75: 25)$ were used as the mobile phase, with the $\mathrm{pH}$ being set at $3.35 \pm 0.2$ with orthophosphoric acid and a flow rate of $1.5 \mathrm{ml} / \mathrm{min}$. The quantification of $\mathrm{FB}_{1}$ was carried out by comparing the peak areas obtained from the samples with those corresponding to the analytical standards of $\mathrm{FB}_{1}$ using PROMEC (Program on mycotoxins and experimental carcinogenesis, Tygerberg, Republic of South Africa).

\section{Statistical analysis}

The concentration-mortality data were subjected to Probit analysis (Finney, 1971) to obtain the $\mathrm{LC}_{50}$ and $\mathrm{LC}_{95}$ values using the SPSS 21.0 software program. In the AChE inhibition, antifungal activity and anti-mycotoxicogenic activity assays, the data were analyzed by one-way analysis of variance (ANOVA). The mean values were compared using Fisher's LSD posteriori test.

\section{RESULTS AND DISCUSSION}

The hydro-distillated EO of L. graveolens from the Dominican Republic was analyzed by GC-MS, identifying thirty-seven different components in the oil (Table 1). According to this analysis, thymol (22.8\%), carvacrol $(22.7 \%)$ and p-cymene $(18.8 \%)$ were the major volatile compounds of Mexican oregano EO, similar to the results reported by Calvo-Irabién et al. (2014) and Rodriguez-Garcia et al. (2016).

In the present study, the EO from oregano was evaluated for use as an insecticide against $S$. zeamais adults. Although pure EO obtained from $L$. graveolens leaves did not show significant mortality of $S$. zeamais after 24 hours of exposure by fumigation at $600.0 \mu \mathrm{l} / \mathrm{l}$ air $\left(\mathrm{LC}_{50}>600.0 \mu \mathrm{l} / \mathrm{l}\right.$ air), p-cymene, a principal compound of oregano EO, presented a higher insecticidal activity and had $\mathrm{LC}_{50}$ and $\mathrm{LC}_{95}$ values of $237.9 \mu \mathrm{l} / \mathrm{l}$ air and $390.3 \mu \mathrm{l} / \mathrm{l}$ air, respectively. Similarly, in another study, Lee et al. (2001) found that p-cymene was an important toxic fumigant against the rice weevil $\left(\mathrm{LC}_{50}=25.0\right.$ $\mu \mathrm{l} / \mathrm{l}$ air). The present results revealed higher $\mathrm{LC}_{50}$ values, possibly due to differences in the experimental procedure causing effects such as interactions taking place between the EO and corn added in the vials. In contrast with the present findings, some authors have reported that EOs of Lippia species present insecticidal (Gleiser \& Zygadlo, 2007; Silva et al., 2008), acaricidal and repellent activities (Ruffinengo et al., 2005; Martinez-
Table 1. Chemical composition of essential oil extracted from Lippia graveolens leaves. RI: identification based on Retention indices; GC-MS: identification based on mass spectra; Co: coinjection with standard. The compounds are listed by elution order in the DB-5 column. $\left(^{*}\right)$ Limonene, $\beta$-phellandrene and 1,8-cineole were also separated on the Carbowax column. Relative contents are expressed as percentages.

\begin{tabular}{|c|c|c|c|}
\hline Compound names & $\mathbf{R} \mathbf{I}$ & $\begin{array}{c}\text { Relative } \\
\text { content } \\
(\%)^{1}\end{array}$ & Identification \\
\hline$\alpha$-thujene & 922 & 1.4 & GC-MS, RI \\
\hline$\alpha$-pinene & 932 & 0.5 & GC-MS, RI, Co \\
\hline$\alpha$-fenchene & 950 & 0.1 & GC-MS, RI \\
\hline$\beta$-pinene & 973 & 0.1 & GC-MS, RI, Co \\
\hline$\beta$-myrcene & 986 & 3.0 & GC-MS, RI, Co \\
\hline$\alpha$-phellandrene & 997 & 0.1 & GC-MS, RI \\
\hline$\delta$-3-carene & 1001 & 0.2 & GC-MS, RI \\
\hline$\alpha$-terpinene & 1009 & 2.3 & GC-MS, RI \\
\hline p-cymene & 1011 & 18.8 & GC-MS, RI, Co \\
\hline limonene & $1019^{*}$ & 0.6 & GC-MS, RI \\
\hline$\beta$-phellandrene & $1019^{*}$ & 0.1 & GC-MS, RI \\
\hline 1,8-cineole & $1021^{*}$ & 3.4 & GC-MS, RI, Co \\
\hline Z- $\beta$-ocimene & 1028 & 0.1 & GC-MS, RI \\
\hline$\gamma$-terpinene & 1050 & 9.6 & GC-MS, RI \\
\hline terpinolene & 1069 & 0.1 & GC-MS, RI \\
\hline p-cymenene & 1073 & 0.1 & GC-MS, RI \\
\hline linalool & 1082 & 0.9 & GC-MS, RI \\
\hline 4-terpineol & 1158 & 1.8 & GC-MS, RI \\
\hline p-cymen-8-ol & 1164 & 0.5 & GC-MS, RI \\
\hline$\alpha$-terpineol & 1172 & 0.9 & GC-MS, RI \\
\hline thymyl methyl ether & 1214 & 0.3 & GC-MS, RI \\
\hline $\begin{array}{l}\text { carvacryl methyl } \\
\text { ether }\end{array}$ & 1221 & 0.1 & GC-MS, RI \\
\hline geranial & 1230 & 0.3 & GC-MS, RI \\
\hline thymol & 1268 & 22.8 & GC-MS, RI, Co \\
\hline carvacrol & 1275 & 22.7 & GC-MS, RI, Co \\
\hline neryl acetate & 1314 & 0.1 & GC-MS, RI \\
\hline$\beta$-caryophyllene & 1418 & 6.8 & GC-MS, RI, Co \\
\hline E- $\alpha$-bergamotene & 1437 & 0.4 & GC-MS, RI \\
\hline aromadendrene & 1440 & 0.1 & GC-MS, RI \\
\hline$\alpha$-humulene & 1451 & 0.7 & GC-MS, RI \\
\hline alloaromadendrene & 1462 & 0.3 & GC-MS, RI \\
\hline$\gamma$-gurjunene & 1471 & 0.1 & GC-MS, RI \\
\hline$\alpha$-muurolene & 1480 & 0.1 & GC-MS, RI \\
\hline$\beta$-bisabolene & 1488 & 0.1 & GC-MS, RI \\
\hline$\gamma$-cadinene & 1498 & 0.1 & GC-MS, RI \\
\hline$\delta$-cadinene & 1508 & 0.2 & GC-MS, RI \\
\hline caryophyllene oxide & 1611 & 0.6 & GC-MS, RI \\
\hline
\end{tabular}


Velazquez et al., 2011; Gomes et al., 2012). These differences in biological activities, with respect to the present study, may have been due to differences in the chemical composition between the EOs of the plant species (Gomes et al., 2012). According to some authors, the main chemical constituents of Mexican oregano EO, thymol and carvacrol, are the ones responsible for insecticide activity (MartinezVelazquez et al., 2011; Gomes et al., 2012), but in the present study, these compounds did not show insecticidal activity at $300.0 \mu \mathrm{l} / \mathrm{l}$ air $\left(\mathrm{LC}_{50}>300 \mu \mathrm{l} / \mathrm{l}\right.$ air). Similarly to the findings of this study, Phillips \& Appel (2010) and Yeom et al. (2012) demonstrated that the fumigant toxicities of carvacrol and thymol were lower than those of other compounds, such as $\alpha$-pinene, $\beta$-pinene and limonene against adult German cockroaches.

Inhibition of AChE activity is one of the most important mechanisms of insecticidal action. The compounds that inhibit or inactivate AChE cause acetylcholine to accumulate at the cholinergic site, which brings about continuous stimulation of the cholinergic nerve fibers throughout the central and peripheral nervous system, resulting in paralysis and death (Siramon et al., 2009). In this study, AChE inhibition in insects exposed to Mexican oregano EO was not observed, but enzyme inactivity was important in vitro $\left(\mathrm{IC}_{50}=7.38 \pm 3.06 \mathrm{mg} /\right.$ $\mathrm{ml}$ ). Although carvacrol and thymol did not reveal insecticidal activity, they produced AChE inhibition. The $\mathrm{IC}_{50}$ of carvacrol could not be determined, but it showed the highest AChE inhibition percentages of all tested concentrations. On the other hand, $\mathrm{p}$ cymene showed insecticide activity and also produced AChE inhibition $\left(\mathrm{IC}_{50}=0.048 \pm 0.015 \mathrm{mg} / \mathrm{ml}\right)$ (Figure 1). Similar results to those of the present study were obtained by Herrera et al. (2015b) using camphor against $S$. zeamais. It was found that this compound produced a strong inhibitory activity on AChE, but did not show any insecticidal activity, probably because of its inability to reach its target site due to a hindrance caused by its topological and physicochemical properties. Related to this, several authors did not find a direct correlation between insect toxicity and AChE inhibition (Lee et al., 2001; Yeom et al., 2012; Yeom et al., 2013; Herrera et al., 2015b) suggesting that there may be different modes of action of monoterpene toxicity to the insects, and consequently, mortality may be caused by other factors (Martinez-Velazquez et al., 2011).

The antifungal activity of Mexican oregano EO was evaluated against $F$. verticillioides M 3125, and the 100 and $200 \mu \mathrm{l} / /$ concentrations of EO were observed to affect the growth and lag phase, while the growth rate showed a significant difference with

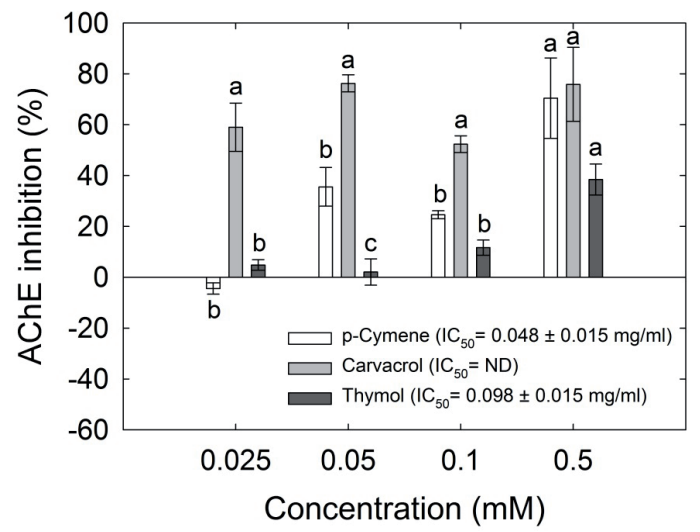

Figure 1. Dose-dependent acetylcholinesterase inhibition (AChE inhibition) in vitro of p-cymene (white column), carvacrol (light gray column) and thymol (gray column). Columns represent the mean value + SE $(n=3)$ for each compound concentration. Different letters indicate significant differences $(P<0.01)$ between compounds. $I C_{50}$ values of thymol and $p$-cymene are shown against Sitophilus zeamais acetylcholinesterase activity.

the control at all the evaluated concentrations with a dose dependent response being found (Table 2). Antimicrobial properties of Mexican oregano have also been reported in other studies, and the present results are in agreement with Portillo-Ruiz et al. (2012), who observed that Lippia berlandieri EO inhibits Aspergillus, Penicillium, and Rhizopus sp. growth and with Mendez et al. (2012) also reporting antibacterial activity of oregano EO against Enterobacter aerogenes, Escherichia coli, Salmonella typhi and Staphylococcus aureus. In the present study, although $\mathrm{FB}_{1}$ production did not show a significant difference with the control, differences among treatments were detected at concentrations of $200 \mu \mathrm{l} / \mathrm{l}$ of EO (Table 2).

Several authors have attributed the antimicrobial activity of the EOs to their phenolic compound contents (Dambolena et al., 2012; Abbaszadeh et al., 2014; Gallucci et al., 2014). In this sense, previous studies have shown that thymol and carvacrol present antifungal activity against $F$. verticillioides, thereby reducing the radial growth, fungal sporulation and $\mathrm{FB}_{1}$ production (Dambolena et al., 2011; Dambolena et al., 2012). Lipophilicity is the main property involved in the antifungal activity of phenolic compounds with this property indicating the possibility that the compounds reach the target site (Dambolena et al., 2012).

Summing up, the present results should encourage research for new active natural compounds in commercial plants, in order to offer an alternative to synthetic pesticides. Mexican oregano EO is an interesting source of compounds which has 
Table 2. Antifungal and antimycotoxicogenic activities of Lippia graveolens essential oil on Fusarium verticillioides M3125

\begin{tabular}{lcccc}
\hline & \multicolumn{4}{c}{ Essential oil concentration $(\mu \mathrm{l} / \mathrm{l})$} \\
\cline { 2 - 5 } & $\mathbf{0}$ & $\mathbf{5 0}$ & $\mathbf{1 0 0}$ & $\mathbf{2 0 0}$ \\
\hline Growth inhibition (\%) & & $50.78 \pm 6.29^{\mathrm{b}}$ & $86.62 \pm 4.59^{\star \mathrm{a}}$ & $93.82 \pm 2.51^{\star \mathrm{a}}$ \\
Growth rate (mm/day) & $7.77 \pm 0.75$ & $5.79 \pm 0.37^{\star \mathrm{b}}$ & $3.29 \pm 0.39^{\star \mathrm{a}}$ & $3.33 \pm 0.39^{\star \mathrm{a}}$ \\
Lag phase (hours) & $33.12 \pm 1.73$ & $43.81 \pm 2.70^{\mathrm{b}}$ & $79.56 \pm 12.06^{\star \mathrm{a}}$ & $118.37 \pm 17.80^{\star \mathrm{a}}$ \\
FB inhibition (\%) & $-47.87 \pm 25.75^{\mathrm{b}}$ & $-83.97 \pm 53.24^{\mathrm{b}}$ & $50.62 \pm 10.71^{\mathrm{a}}$ \\
\hline
\end{tabular}

Values are expressed as means \pm SE; ${ }^{1}$ Inhibition of fungal growth was determined after 5 days of incubation. ${ }^{*}$ Indicates significant difference with the control, and values having different letters are significantly different for each treatment. The experiments were performed twice in triplicate $(P<0.05)$.

grain-protectant properties against $F$. verticillioides and S. zeamais, and should be analyzed in future studies in order to develop new biopesticides to be used in integrated pest management plans of stored grains. Due to the practical use of biopesticides developed from EOs further studies are necessary to elucidate their mode of action, side effects, and formulation development in order to improve their efficacy and stability. Moreover, toxicity and in vivo efficacy studies using formulated products are clearly required, and the economic feasibility of these products developed from EOs has still to be demonstrated.

\section{ACKNOWLEDGEMENTS}

This work complies with Argentinean laws. The authors would like to thank the Director of IIBI, Dra Castillo de la Cruz B., and Dr. Almanzar H.A.R. for providing facilities to carry out this work. The authors acknowledge Dr. Paul Hobson for reviewing the manuscript. The authors also declare that there is no conflict of interest. Financial support for this work came from the following sources: FONCYT (PICT 2012-2146), CONICET (PIP 11220120100661CO) and Universidad Nacional de Córdoba (SECyT).

\section{REFERENCES}

Abbaszadeh, S.; A. Sharifzadeh, H. Shokri, A. Khosravi and A. Abbaszadeh, 2014. Antifungal efficacy of thymol, carvacrol, eugenol and menthol as alternative agents to control the growth of food-relevant fungi. Journal de Mycologie Médicale 24: e51-e56.

Bueno-Durán, A.Y.; J. Cervantes-Martínez, E.N. ObledoVázquez, 2013. Composition of essential oil from Lippia graveolens. Relationship between spectral light quality and thymol and carvacrol content. Journal of Essential Oil Research 26: 153-160.

Calvo-Irabién, L.M.; V. Parra-Tabla, V. Acosta-Arriola, F.
Escalante-Erosa, L. Díaz-Vera, G.R. Dzib and L.M. Peña-Rodríguez, 2014. Phytochemical diversity of the essential oils of Mexican oregano (Lippia graveolens Kunth) populations along an edapho-climatic gradient. Chemistry \& Biodiversity 11: 1010-1021.

Caneppele, M.;C. Caneppele,F. Lázzari and S.Lázzari, 2003. Correlation between the infestation level of Sitophilus zeamais Motschulsky, 1855 (Coleoptera, Curculionidae) and the quality factors of stored corn, Zea mays L.(Poaceae). Revista Brasileira de Entomologia 47: 625-630.

Cavalcanti, E.S.B.; S.M. de Morais, M.A.A. Lima and E.W.P. Santana, 2004. Larvicidal activity of essential oils from Brazilian plants against Aedes aegypti L. Memórias do Instituto Oswaldo Cruz 99: 541-544.

Dambolena, J.S.; J.A. Zygadlo and H.R. Rubinstein, 2011. Antifumonisin activity of natural phenolic compounds: a structure-property-activity relationship study. International Journal of Food Microbiology 145: 140-146.

Dambolena, J.S.; A.G. López, J.M. Meriles, H.R. Rubinstein, J.A. Zygadlo, 2012. Inhibitory effect of 10 natural phenolic compounds on Fusarium verticillioides. A structure-property-activity relationship study. Food Control 28: 163-170.

Ellman, G.L.; K.D. Courtney, V. Andres Jr. and R.M. Featherstone, 1961. A new and rapid colorimetric determination of acetylcholinesterase activity. Biochemical Pharmacology 7: 88-95.

FAO, 1974. Método provisional para gorgojos adultos importantes en cereales almacenados con malation o lindano. Boletín Fitosanitario de la FAO. Método №15 la FAO 22: 127-137.

Finney, D., 1971. Probit Analysis. Cambridge University Press.

Gallucci, M.; M. Carezzano, M. Oliva, M. Demo, R. Pizzolitto, M. Zunino, J. Zygadlo and J. Dambolena, 2014. In vitro activity of natural phenolic compounds against fluconazole-resistant Candida species: a quantitative structure-activity relationship analysis. Journal of Applied Microbiology 116: 795-804.

Gleiser, R. and J. Zygadlo, 2007. Insecticidal proper- 
ties of essential oils from Lippia turbinata and Lippia polystachya (Verbenaceae) against Culex quinquefasciatus (Diptera: Culicidae). Parasitology Research 101: 1349-1354.

Gleiser, R. and J. Zygadlo, 2009. Essential oils as potential bioactive compounds against mosquitoes. In Imperato, F.; R.M. Gleiserand J.A. Zygadlo (Eds.): Recent advances in phytochemistry. Research Signpost, Trivandrum, Kerala, India, 24 pp.

Gomes, G.; C. Monteiro, T. Senra, V. Zeringota, F. Calmon, R. Matos, E. Daemon, R. Gois, G. Santiago and M. de Carvalho, 2012. Chemical composition and acaricidal activity of essential oil from Lippia sidoides on larvae of Dermacentor nitens (Acari: Ixodidae) and larvae and engorged females of Rhipicephalus microplus (Acari: Ixodidae). Parasitology Research 111: 2423-2430.

Herrera, J.M.; R.P. Pizzolitto, M.P. Zunino, J.S. Dambolena and J.A. Zygadlo, 2015a. Effect of fungal volatile organic compounds on a fungus and an insect that damage stored maize. Journal of Stored Products Research 62: 74-80.

Herrera, J.M.; M.P. Zunino, J.S. Dambolena, R.P. Pizzolitto, N.A. Gañan, E.I. Lucini and J.A. Zygadlo, 2015b. Terpene ketones as natural insecticides against Sitophilus zeamais. Industrial Crops and Products 70: 435-442.

Hernández-Lambraño, R.; K. Caballero-Gallardo and J. Olivero-Verbel, 2014. Toxicity and antifeedant activity of essential oils from three aromatic plants grown in Colombia against Euprosterna elaeasa and Acharia fusca (Lepidoptera: Limacodidae). Asian Pacific Journal of Tropical Biomedicine 4: 695-700.

Isman, M.B., 2006. Botanical insecticides, deterrents, and repellents in modern agriculture and an increasingly regulated world. Annual Review of Entomology 51: 4566.

Lee, S.-E.;B.-H. Lee, W.-S. Choi, B.-S. Park, J.-G. Kim and B.C. Campbell, 2001. Fumigant toxicity of volatile natural products from Korean spices and medicinal plants towards the rice weevil, Sitophilus oryzae (L). Pest Management Science 57: 548-553.

Leslie, J.; R. Plattner, A. Desjardins and C. Klittich, 1992. Fumonisin B1 production by strains from different mating populations of Gibberella fujikuroi (Fusarium section Liseola). Phytopathology 82: 341-345.

Leslie, J.F.; B.A. Summerell and S. Bullock, 2006. The Fusarium laboratory manual. Vol. 2 (Wiley Online Library, 2006).

Martinez-Velazquez, M.; R. Rosario-Cruz, G. CastilloHerrera, J.M. Flores-Fernandez, A.H. Alvarez and E. Lugo-Cervantes, 2011. Acaricidal effect of essential oils from Lippia graveolens (Lamiales: Verbenaceae), Rosmarinus officinalis (Lamiales: Lamiaceae), and Allium sativum (Liliales: Liliaceae) against Rhipicepha-
Ius (Boophilus) microplus (Acari: Ixodidae). Journal of Medical Entomology 48: 822-827.

Mendez, M.; R. Rodríguez, J. Ruiz, D. Morales-Adame, F. Castillo, F.D. Hernández-Castillo and C.N. Aguilar, 2012. Antibacterial activity of plant extracts obtained with alternative organics solvents against food-borne pathogen bacteria. Industrial Crops and Products 37: 445-450.

Mohammadi-Farani, A.; A. Ahmadi, H. Nadri and A. Aliabadi, 2013. Synthesis, docking and acetylcholinesterase inhibitory assessment of 2-(2-(4-Benzylpiperazin-1-yl)ethyl)isoindoline-1,3-dione derivatives with potential anti-Alzheimer effects. DARU Journal of Pharmaceutical Sciences 21: 47-47.

Phillips, A.K. and A.G. Appel, 2010. Fumigant toxicity of essential oils to the German cockroach (Dictyoptera: Blattellidae). Journal of Economic Entomology 103: 781-790.

Pimentel, M.A.G.; L.R.D.A. Faroni, R.N.C. Guedes, A.H. Sousa and M.R.Tótola, 2009. Phosphine resistance in Brazilian populations of Sitophilus zeamais Motschulsky (Coleoptera: Curculionidae). Journal of Stored Products Research 45: 71-74.

Portillo-Ruiz, M.C.; R.A.S. Sánchez, S.V. Ramos, J.V.T. Muñoz and G.V. Nevárez-Moorillón, 2012. Antifungal effect of mexican oregano (Lippia berlandieriSchauer) essential oil on a wheat flour-based medium. Journal of Food Science77: M441-M445.

Rajendran, S. and V. Sriranjini, 2008. Plant products as fumigants for stored-product insect control. Journal of Stored Products Research 44: 126-135.

Regnault-Roger, C.; C. Vincent and J. Arnason, 2012. Essential oils in insect control: low-risk products in a high-stakes world. Annual Review of Entomology 57: 405-424.

Rodriguez-Garcia, I.; M.R. Cruz-Valenzuela, B.A. SilvaEspinoza, G.A. Gonzalez-Aguilar, E. Moctezuma, M.M. Gutierrez-Pacheco, M.R. Tapia-Rodriguez, L.A. Ortega-Ramirez and J.F. Ayala-Zavala, 2016. Oregano (Lippia graveolens) essential oil added within pectin edible coatings prevents fungal decay and increases the antioxidant capacity of treated tomatoes. Journal of the Science of Food and Agriculture 96 (11):37723778.

Ruffinengo, S.; M. Eguaras, I. Floris, C. Faverin, P. Bailac and M. Ponzi, 2005. LD 50 and repellent effects of essential oils from Argentinian wild plant species on Varroa destructor. Journal of Economic Entomology 98: 651-655.

Shephard, G.S.; W.F. Marasas, N.L. Leggott, H. Yazdanpanah, H. Rahimian and N. Safavi, 2000. Natural occurrence of fumonisins in corn from Iran. The Journal of Agricultural and Food Chemistry48: 1860-1864. 
Silva, W.J.;G.A.A. Dória, R.T. Maia, R.S. Nunes, G.A. Carvalho, A.F.Blank, P.B. Alves, R.M. Marçal and S.C.H. Cavalcanti, 2008. Effects of essential oils on Aedes aegypti larvae: Alternatives to environmentally safe insecticides. Bioresource Technology 99: 3251-3255.

Siramon, P.; Y. Ohtani and H. Ichiura, 2009. Biological performance of Eucalyptus camaldulensis leaf oils from Thailand against the subterranean termite Coptotermes formosanus Shiraki. Journal of Wood Science 55: 41-46.

Sousa, R.M.O.F.; J.S. Rosa, L. Oliveira, A. Cunha and M. Fernandes-Ferreira, 2015. Activities of Apiaceae essential oils and volatile compounds on hatchability, development, reproduction and nutrition of Pseudaletia unipuncta (Lepidoptera: Noctuidae). Industrial Crops and Products 63: 226-237.

Stockmann-Juvala, H. and K. Savolainen, 2008. A review of the toxic effects and mechanisms of action of fumonisin B1. Human and Experimental Toxicology 27: 799-809.

Theumer, M.; M. Cánepa, A. López, V. Mary, J.S. Dambo- lena and H. Rubinstein, 2010. Subchronic mycotoxicoses in Wistar rats: Assessment of the in vivo and in vitro genotoxicity induced by fumonisins and aflatoxin B 1, and oxidative stress biomarkers status. Toxicology 268: 104-110.

Trematerra, P.;R. Ianiro, C.G. Athanassiou and N.G. Kavallieratos, 2013. Behavioral responses of Sitophilus zeamais Motschulsky adults to conditioned grain kernels. Journal of Stored Products Research 53: 77-81.

Yeom, H.; J. Kang, G. Kim and I. Park, 2012. Insecticidal and acetylcholine esterase inhibition activity of Apiaceae plant essential oils and their constituents against adults of German cockroach (Blattella germanica). Journal of Agricultural and Food Chemistry 60: 71947203.

Yeom, H.-J.; J. Kang, S.-W. Kim and I.-K. Park, 2013. Fumigant and contact toxicity of Myrtaceae plant essential oils and blends of their constituents against adults of German cockroach (Blattella germanica) and their acetylcholinesterase inhibitory activity. Pesticide Biochemistry and Physiology107: 200-206. 